\title{
Female genital mutilation/cutting: risk management and strategies for social workers and health care professionals
}

This article was published in the following Dove Press journal:

Risk Management and Healthcare Policy

15 December 2015

Number of times this article has been viewed

\section{Susan Costello}

School of Global, Urban and Social Studies, RMIT University, Melbourne, VIC, Australia
Correspondence: Susan Costello School of Global, Urban and Social Studies, RMIT University, 360 Swanston Street, Melbourne 300I, VIC, Australia Email susan.costello@rmit.edu.au
Abstract: Female genital mutilation/cutting (FGM/C) is a traditional practice originating in Africa. Its worst forms cause irreparable harm to girls and women and have no medical justification. Based on a literature review of global responses to FGM/C and conversations with Australian women who migrated from FGM/C practicing countries, this paper provides some background on FGM/C and its epidemiology, outlining its prevalence, types, and health risks and complications for women and girls. It discusses risk-prevention strategies, first, for health practitioners in identifying, screening, and supporting women affected by FGM/C and, second, for welfare and social workers and health care professionals to identify, work with, and prevent girls from being cut. Consistent with international trends in addressing the risks of FGM/C, the paper suggests practice responses for coordinated responses between professionals, communities from practicing countries, and governments of different countries.

Keywords: female genital mutilation, female genital cutting, female circumcision, child protection, risk management

\section{Introduction}

This study originated from research conducted between 2011 and 2014 by RMIT University for Family Planning Victoria (FPV) in Australia. ${ }^{1}$ The research was conducted in conversation with African background Australian women whose work in education for prevention of female genital mutilation/cutting (FGM/C) was coordinated by FPV. The women provided insights about the cultural, historical, social, and religious context for the practices and prevention strategies; for example, that the terminology and practice is an emotionally charged and contested issue. Based on the women's insights and an international literature review, this paper outlines FGM/C practices, types, prevalence, motivations, risks, and global prevention strategies. Recommendations for health and social welfare responses derive from the premise that cultural awareness and respect are fundamental to managing the risk of FGM/C.

FGM/C is defined by the World Health Organization (WHO), United Nations Children's Fund (UNICEF), and United Nations Population Fund (UNFPA) in their Joint Statement 1997 "as all procedures involving partial or total removal of the external female genitalia or other injury to the female genital organs for nonmedical reasons". ${ }^{2}$

The procedure is usually done between the ages of 4 and 8 years, but sometimes in the 1 st week of life or at prepuberty, rarely later than 16 years. In the 29 countries in Africa and the Middle East where FGM/C is concentrated, more than 125 million girls and women alive today have been cut. In Egypt, this is around one in five. ${ }^{3}$ In half 
of the countries, the majority of girls were cut before the age of 5 . In the rest of the countries, most cutting occurs between 5 and 14 years of age depending on the different cultural, social, and religious understandings of the practice. ${ }^{4}$

\section{Cultural, social, and religious bases of FGM/C}

The United Nations uses the term "female genital mutilation" to convey that this practice is a violation of the human rights of girls and women and to promote national and international advocacy toward its abandonment. Yet the word "mutilation" does not sit well with women and affected communities as, in their eyes, the procedure is linked to beautification, femininity, virtue, and virginity. The terms favored within practicing communities are "female genital cutting", "female circumcision", and other local terms. Calling it "circumcision" however positively associates the practice with the "least severe forms of male genital cutting, done in the most sterile environments, with the least drastic consequences" rather than acknowledging the serious risks in female cutting. ${ }^{5}$ In recognition of community concerns about the language of "mutilation", the term "female genital mutilation/cutting" (abbreviated as FGM/C) is generally used throughout this paper, except when referencing or quoting other writers.

FGM/C practices are deeply entrenched in the cultural and societal meanings, beliefs, and values in the affected countries. Expectations about gender, sexuality, marriage, and family determine what is considered "proper" sexual behavior of women in relation to "premarital virginity and marital fidelity"3 FGM/C is associated with cultural ideals of femininity, chastity, and modesty and is thought to reduce a woman's libido. In the eyes of families and communities, "circumcision" is not motivated by malice or violence, but by the family's consideration of the best interests of the child. ${ }^{6,7}$

$\mathrm{FGM} / \mathrm{C}$ functions as a self-enforcing social convention or social norm. In societies where it is practiced, it is a socially upheld behavioral rule. Families and individuals uphold the practice because they believe that their group or society expects them to do so. ${ }^{4}$ In practicing African countries, failure to have one's daughter circumcised will probably mean that the girl will be stigmatized and excluded, even subjected to violence. She may well not be marriageable and her family may be shamed, ostracized, and discriminated against and subjected to violence. ${ }^{8} \mathrm{~A}$ woman in this study reported a family in Africa cast out of their community when their daughter's new husband discovered his wife was not circumcised. ${ }^{9}$
From a Western perspective of (comparative) gender equality (for middle class educated women), $\mathrm{FGM} / \mathrm{C}$ is seen as "a manifestation of deep-rooted gender inequality that assigns (women) an inferior position in society and has profound physical and social consequences". ${ }^{7}$ It evolved as a means of male control of women early in Egyptian civilization and may have evolved in sub-Sahara millennia earlier. $^{10}$

Yet FGM/C today is women's business, conducted by older female traditional cutters as a necessary ritual of cultural inclusion for girl children. An African Australian woman in this study described defying her parents' refusal to have her circumcised, sneaking off to the traditional circumciser to be cut so that she was the same as her 8 -year-old girlfriends. ${ }^{9}$ The drive to belong and conform is a powerful one.

Caldwell et al observe that in much of Africa, traditional life and religion are very close - "life was an expression of religion and religion hallowed life". ${ }^{10}$ The Innocenti Research Centre argues that because culture, tradition, and religion are so interconnected it is incorrectly assumed that FGM/C is linked to religion, and particularly to the Islamic faith. ${ }^{11}$ In Africa, just under $60 \%$ of women affected by $\mathrm{FGM} / \mathrm{C}$ are Islamic, just under $40 \%$ identify as Christian, and $\mathrm{FGM} / \mathrm{C}$ is also found in some small Jewish communities and amongst people practicing traditional African beliefs. ${ }^{10}$

$\mathrm{FGM} / \mathrm{C}$ however is not sanctioned by any religion. Theologians in three religions, Islam, Christianity, and Judaism hold that FGM/C is not consistent with their scriptures - the Q'uran, Bible, or Torah. ${ }^{9}$ Whist FGM/C's ancient Egyptian origins predate both Islam and Christianity, FGM/C is not practiced in the most populous Islamic countries in the world, a reality that further negates its connection with Islam. ${ }^{10}$

Different groups practice different types of FGM/C. The most severe form, infibulation, is practiced in predominantly Islamic countries in Africa and associated with Islamic culture in those parts of the world.

\section{Types}

The WHO identifies four types of FGM/C practiced in different contexts and countries. The first type is Clitoridectomy where part or all of the clitoris and surrounding tissue is removed. The second type is called Excision and refers to the partial or total removal of the clitoris as well as the labia minora, with or without excision of the labia majora. These two types are the most common, comprising about $80 \%$ of all FGM/C practice. The third type, infibulation, 
the most severe type, involves excision of part or all of the external genitalia and stitching or narrowing the vaginal opening. Infibulation necessitates subsequent surgery or cutting (de-infibulation) or other forms of force to open the vagina for sexual intercourse and childbirth. Some women are restitched after each birth, going through repeated opening and closing procedures, which heightens both immediate and long-term risks. ${ }^{3}$

The fourth type referred to as nicking or pricking includes all other harmful procedures to female genitalia for nonmedical purposes, such as pricking, piercing, incising, scraping, and cauterization of the clitoris. Other practices include gishiri or angurya (cuts) around the vagina or using substances to dry and tighten the vagina prior to sexual intercourse. ${ }^{12}$ Type IV FGC/M is practiced in parts of Indonesia, India, Israel, Iraq, Malaysia, Thailand, and United Arab Emirates. ${ }^{2}$ While some Type IV procedures do not mutilate or cut, they are still unconsented acts on a child's genitalia.

Different cultural meanings, beliefs, and associated rituals and celebrations, underpin FGM/C practices, many of which are highly valued by girls and women in practicing communities, a significant consideration in the transition from the traditional practice.

Whilst the 2008 WHO definition includes all procedures involving injury to the female genital organs for nonmedical reasons, there are different health and psychological consequences of the different types of FGM/C. ${ }^{5}$ The particular and specific meanings, beliefs, myths, and their associated practices vary between regions, localities, and tribes, as does its prevalence.

\section{Prevalence}

Despite significant efforts being taken to eradicate FGM/C, over 100-140 million women are affected by the practice worldwide. ${ }^{4}$ The practice of $\mathrm{FGM} / \mathrm{C}$ is concentrated in 28 countries, 27 in northern Africa and in Yemen. It is also found within regions in Middle Eastern countries such as Iran, Iraq, Saudi Arabia, Jordan, Oman, and Israel (Occupied Territories of Gaza); in Asian countries such as India, Malaysia, and Indonesia; and in parts of South America. ${ }^{13}$ Table 1 indicates the prevalence rates of Types I-III FGM/C and countries that have laws against the practice.

Global figures depicting the prevalence of FGM/C obscure significant differences. First, there are regional and ethnic differences. For example, the national prevalence of FGM/C in Nigeria is $19 \%$ whilst it is almost $60 \%$ in the southern regions of Nigeria. ${ }^{7}$ Second, the different forms of FGM/C have different levels of associated severity and harm, with some forms of Type IV being argued as nonharming. ${ }^{14}$

Over the past few decades, through migration and refugee flight, women and girls who have been subjected to or who may be at risk of $\mathrm{FGM} / \mathrm{C}$ have resettled in Western countries, including Europe, USA, Canada, Australia, and New Zealand. Anecdotal evidence implies that women and girls have been cut before arrival or while traveling outside host countries, for which the legal principle of extraterritoriality has become important. No concrete evidence indicates the continuance of FGM/C in these countries, but occasional prosecutions indicate that that the health risks will not be tolerated in host countries. ${ }^{16}$

\section{Health risks and complications for girls, women, and children}

There is no evidence of any health benefits from FGM/C. Instead, apart from Type IV, nicking and pricking of the clitoris, the other three types can cause irreparable physical, psychological, emotional, and spiritual harm to girls and women. They cause harm at the time of occurrence, throughout the lives of girls and women, and, potentially, for their babies at the time of birth. They interfere with natural body functions and can cause recurrent bladder and urinary tract infections and reduced sexual pleasure. Aseptic conditions and absence of anesthetics mean that some girls suffer unbearable pain, shock, hemorrhage, tetanus, sepsis, and open sores. ${ }^{17,18}$

Some women suffer psychological and psychosomatic disorders such as sleep, mood and cognition changes, depression, chronic anxiety, and panic attacks as a result of FGM/C. ${ }^{3,17}$ Infibulated women requiring surgery to allow for sexual intercourse or childbirth face significantly more difficulties in childbirth, higher rates of infant mortality, and infertility. ${ }^{17}$ While the physical impact of the fourth type, nicking or pricking an infant girl's clitoris, is minimal, the psychological and emotional impacts are unknown.

The different forms of cutting listed above are likely to have different degrees of harm, different effects on sexual function and satisfaction, and different risks of developing infection. ${ }^{5}$ In recent decades, a growing number of parents from migrant communities have taken their girls to Western public hospitals requesting circumcision for cultural reasons, unaware that the procedure is illegal. ${ }^{19}$ Laws prohibiting FGM/C are one form of risk management of $\mathrm{FGM} / \mathrm{C}$. 
Table I Countries grouped according to prevalence, types I, II, and III and laws against FGM/C

\begin{tabular}{|c|c|c|c|}
\hline Categories & $\begin{array}{l}\text { Prevalence of girls and women } \\
\text { of reproductive age who report } \\
\text { having been cut, and Type of FGC/M }\end{array}$ & Countries & $\begin{array}{l}\text { Countries with laws } \\
\text { against FGM/C }\end{array}$ \\
\hline $\begin{array}{l}\text { I. Very high prevalence } \\
\text { countries, almost } \\
\text { universal }\end{array}$ & $\begin{array}{l}\text { Over } 80 \% \text { of girls and women } \\
\text { of reproductive age reported having been } \\
\text { cut, } 30 \% \text { Type III }\end{array}$ & $\begin{array}{l}\text { Somalia (98\%), Guinea (96\%), } \\
\text { Djibouti (93\%), Egypt (91\%). } \\
\text { Eritrea (89\%), Mali (89\%), } \\
\text { Sierra Leone (88\%), Sudan (88\%). }\end{array}$ & $\begin{array}{l}\text { Djibouti, Egypt. Eritrea, } \\
\text { Guinea, Somalia, Sudan. }\end{array}$ \\
\hline $\begin{array}{l}\text { 2. Moderately high } \\
\text { prevalence countries }\end{array}$ & $\begin{array}{l}\text { Between } 51 \% \text { and } 80 \% \text { of girls and women } \\
\text { cut, predominantly Types I and II }\end{array}$ & $\begin{array}{l}\text { Gambia }(76 \%) \text {, Burkina Faso }(76 \%) \text {, } \\
\text { Ethiopia }(74 \%) \text {, Mauritania }(69 \%) \text {, } \\
\text { Liberia }(66 \%) .\end{array}$ & $\begin{array}{l}\text { Burkina Faso, Ethiopia, } \\
\text { Mauritania. }\end{array}$ \\
\hline $\begin{array}{l}\text { 3. Moderately low } \\
\text { prevalence countries }\end{array}$ & $\begin{array}{l}\text { Between } 26 \% \text { and } 50 \% \text { of girls and women } \\
\text { cut, predominantly Types I and II }\end{array}$ & $\begin{array}{l}\text { Guinea Bissau (50\%), Chad ( } 44 \%) \text {, } \\
\text { Cote D'Ivoire (38\%), Kenya ( } 27 \%) \text {, } \\
\text { Nigeria ( } 27 \%) \text {, Senegal }(26 \%) .\end{array}$ & $\begin{array}{l}\text { Chad, Cote D’lvoire, } \\
\text { Kenya, Senegal, Guinea } \\
\text { Bissau, Nigeria. }\end{array}$ \\
\hline 4. Low prevalence & $\begin{array}{l}\text { Between } 10 \text { and } 25 \% \text {, predominantly } \\
\text { Types I and II }\end{array}$ & $\begin{array}{l}\text { Central African Republic (24\%), } \\
\text { Yemen (23\%), United Republic of } \\
\text { Tanzania (15\%), Benin (13\%). }\end{array}$ & $\begin{array}{l}\text { Central African Republic, } \\
\text { Benin, United Republic } \\
\text { of Tanzania. }\end{array}$ \\
\hline 5. Very low prevalence & Below $10 \%$ & $\begin{array}{l}\text { Iraq (8\%), Ghana (4\%), Togo (4\%), } \\
\text { Niger ( } 2 \%) \text {, Cameroon (I\%), } \\
\text { Uganda (I\%). }\end{array}$ & Ghana, Niger, Togo. \\
\hline
\end{tabular}

Notes: Data from UNICEF 2013, ${ }^{4}$ and Macfarlane and Dorkenoo. ${ }^{15}$

Abbreviation: FGM/C, female genital mutilation/cutting.

\section{Risk management strategies against FGM/C in Africa and migrant countries}

In most countries where $\mathrm{FGM} / \mathrm{C}$ is practiced, most girls and women think it should end. Support for FGM/C is stronger amongst girls and women in poor households than in the richest households, and women and girls who are educated are less likely to support the practice of FGM/C. ${ }^{4}$

Strategies to prevent the practice include legislation, health and human rights education, and community empowerment. This paper will examine the role and impact of legislation then consider responses to reduce the risk of harm to women and children in affected communities.

In 1994, the UN Conference on Human Rights declared FGM/C a violation of human rights, urging governments "to prohibit female genital mutilation wherever it exists and to give vigorous support to efforts among non-governmental and community organizations and religious institutions to eliminate such practices". ${ }^{20}$ The effectiveness of these charters is only realized when communities decide they are consistent with their own cultural and religious values and develop their own legislation. ${ }^{21}$ Governments of 22 African nations have introduced legislation against $\mathrm{FGM} / \mathrm{C}$, and 18 countries that receive migrants from $\mathrm{FGM} / \mathrm{C}$ practicing countries have enacted laws criminalizing FGM/C with penalties from fines to incarceration ranging from 3 months to a life sentence. ${ }^{4,12}$

References to FGM/C are found in policy and legislative documents in the European Union (EU). The European
Parliament, EU Commission, and Council of the EU have called for a coordinated European response to violence against women, including domestic violence and female genital mutilation. The European Commission's $€ 15$ million commitment to the Daphne Programme has created a European network to stop FGM/C and ensure cooperation between academic and research institutes and grassroots organizations. ${ }^{12}$

France and the UK host the largest migrant communities from countries that practice FGM/C. France uses the highest criminal court to penalize offenders, mainly mothers or second wives, as practitioners are harder to identify and prosecute. ${ }^{22}$

The UK has specific FGM/C child protection legislation that mandates professionals to report to social services, rather than to the police, ${ }^{23}$ with the first prosecution occurring in 2015. ${ }^{16}$ Ireland and Scotland have specific FGM/C legislation that secure children's right to protection and women's access to specialized medical care, free financial assistance, and medical advice. Penalties for committing FGM/C include extraterritorially (prohibition against arranging or committing the practice overseas) in these countries. ${ }^{12}$

Whist not specifying FGM/C, European Child Protection laws serve to prevent $\mathrm{FGM} / \mathrm{C}$ occurring through measures such as removing the girl from her family or suspending parental passports through court processes. Such interventions have taken place in Denmark, Finland, France, Germany, Italy, the Netherlands, Spain, Sweden, and the UK. Fourteen European countries having granted asylum on the basis of 
fear of being subjected to FGM/C include Latvia, Lithuania, Romania, Slovakia, and Hungary. ${ }^{12}$

The Swedish system combines preventative education with child protection surveillance and intervention. An effective, well-integrated child protection "Alert System" comprises networks of educational, health, and social authorities. Professionals are well educated about FGM/C and the law, are alert to signs that may indicate intention or occurrence, and know the processes for reporting. The child protection system operates in conjunction with community education and debate about FGM/C amongst practicing migrant groups, and mass media campaigns raise awareness to promote its abandonment. ${ }^{24}$ By 2009 , only two cases in Sweden had invoked custodial sentences, both associated with other risk issues. ${ }^{25}$

Australia has robust, clear prohibitions against FGM/C in legislation and medical policy. It is illegal for anyone to perform or procure any type of FGM/C, to take a child out of the country for this purpose or to re-infibulate a woman even if she requests it. ${ }^{26}$

The role of legislation and legal interventions in deterring FGC is complex. To be effective, the law and associated processes must be widely known, understood, and implemented effectively. While there is some evidence of deterrence under the French and Swedish systems of child protection, monitoring, and prosecution, ${ }^{25}$ unintended consequences raise questions about the way the laws are enacted.

Prohibition in Western countries increases secrecy and strategies to avoid detection, such as delaying FGM/C until girls are older than the age of surveillance. ${ }^{22}$ It can create barriers to affected women and children seeking medical care even for unrelated matters. Penalizing women who are themselves victims of FGM/C divides families whose daughters may view their mothers and grandmothers as criminals and further stigmatizes and marginalizes girls and women in affected communities, which can reinforce traditional beliefs. ${ }^{27} \mathrm{FGM} / \mathrm{C}$ is difficult to detect because of its private and taboo nature, the invasive process of monitoring girls' genitalia and because Types I, II, and IV cannot always be detected through observation. ${ }^{25}$ Monitoring can be perceived as racist and intrusive.

Despite these concerns, many migrants in affected communities appreciate laws against FGM/C. "Many girls must have suffered before the law came. It should have come a little earlier and have been more severe" said an African background woman in Johnsdotter et al's 2009 study in Sweden. ${ }^{25}$

While legislation may act as a disincentive, its importance lies in underpinning an integrated, holistic framework for the prevention of FGM/C, which embraces culturally informed, collaborative interventions that respectfully involve communities working with health, welfare, and child protection professionals. ${ }^{12,28}$ Different professions should be aware of their roles and responsibilities in responding to women and children affected by or at risk of $\mathrm{FGM} / \mathrm{C}$ to influence the traditional cultural practice of FGM/C.

\section{Role and responsibilities of health professionals}

FGM/C raises complex medical, cultural, legal, and ethical challenges for health practitioners, as outlined above. Health professionals can become caught in dilemmas where the law prohibits them from responding to the (culturally based) wishes of their patients to be re-infibulated or to perform hygienic circumcision instead of leaving it to traditional practitioners in their homes in the community.

Some governments, Indonesia for example, condone "medicalization" of FGM/C. ${ }^{14}$ Medicalization refers to the procedures being performed by health care professionals rather than traditional practitioners or the use of medical instruments, antibiotics and/or anesthetics by traditional practitioners. "Clinicalization" is when the procedures are conducted in a health care facility. The International Federation of Gynecology and Obstetrics passed a resolution in 1994 at its General Assembly opposing the performance of FGM/C under any circumstances, in health establishments or by health professionals. ${ }^{4}$ It is the responsibility of health and welfare professionals to be informed and aware of their roles and responsibilities about FGM/C.

Health professionals, policy advocates, and researchers have developed information guides for health practitioners in working with affected women in Australia, ${ }^{28}$ Ireland, ${ }^{29}$ and the UK. ${ }^{30}$ Some of their suggestions are summarized here.

First, in order to ensure the woman's first encounter or consultation is a positive experience, health practitioners need to be familiar with the types of FGM/C, the global areas of high FGM/C prevalence (Table 1), the cultural predeterminants of the practice, the indications that a girl may be at risk of being cut, the laws, and who to contact in the case of suspecting that a family may be planning to organize a circumcision. ${ }^{29}$ Child protection procedures will be discussed in relation to the social worker's role later in the paper.

Second, medical practitioners should develop skills to engage with women in the sensitive, personal, and secretive area of risk of FGM/C. People from practicing countries may have inadequate knowledge of their bodies and biological facts and be shocked and angry when they learn that FGM/C 
is not a universal practice, and is illegal as one of the women in this study reported:

I first realised that traditional cutting is harmful when I had my first Pap smear examination [in Australia]. My examiner seemed to be a bit shocked at what she was seeing. She had to ask for another medical practitioner to come and have a look. From there on I learnt something's not quite right and that mainstream women are not circumcised - I had two shocks at the same time. ${ }^{8}$

Third, professionals unfamiliar with the culture should develop ways of talking about FGM/C with affected women. ${ }^{28}$ Jordan and Neophytou ${ }^{28}$ suggest using sensitive, simple language and direct questions so that women and girls feel comfortable to discuss their issues and return for further services. They recommend referring to FGM/C practices in local terms to convey cultural respect and allay women's fear of discrimination and judgment.

Simple straightforward statements or question are recommended, such as: "I know that in some African and other countries, circumcision is common so I'm wondering, have you been cut down below? Have you been circumcised/cut/closed?" Some women will not remember the procedure that was done when they were a child, so an examination by an appropriate health professional will be required to assess the woman's needs. ${ }^{29}$

Fourth, obstetric problems caused by FGM Types I, II, and III, such as vaginal and vulvar scarring and adhesions of the vaginal wall complicate pregnancy and childbirth and warrant early assessment and preparation to enable the woman to become familiar with her care team and for the team to be aware of potential difficulties. Documenting the presence, type, and impact of FGM/C is important in developing a birth plan addressing analgesia and anesthesia in labor and for future pregnancies. ${ }^{29}$ In the UK, it is mandatory for health professionals to record the presence of FGM/C in a patient's health care record whenever it is identified to ensure the delivery of appropriate health care. It is mandatory to report the number of patients who have FGM/C in patient caseloads to the UK Department of Health. ${ }^{30}$

In order to commence a sexual relationship or to give birth, women who have undergone Type III FGM/C (infibulation) may require de-infibulation, which should be done early in the pregnancy to allow the area to heal before delivery. Women who present late in their pregnancy, for a number of reasons, risk laceration, hemorrhage, or tearing, causing a fistula, requiring surgical management. ${ }^{29}$ Infibulated women should be informed that de-infibulation is an available option. They should be informed about the benefits of de-infibulation and referred to specialist clinics that offer a range of health care services. ${ }^{30}$

Fifth, gynecologists may need to assist women with complications that arise as a result of being cut or sewn as a child in aseptic, infection-inducing environments. Plans for extended and intense postnatal care may be needed for infibulated women, since perinatal tears and episiotomies are common during birth with infibulated women. ${ }^{29}$

In summary, the challenges for health practitioners include the following: being aware and informed about the physiology of the different types of FGM/C and how to respond in culturally-sensitive, respectful, confidential, and competent ways; caring for infibulated women requiring deinfibulation for sexual intercourse or childbirth; monitoring and screening for FGM/C by inquiring about genital surgery; responding to requests by women for illegal procedures such as re-infibulation after childbirth or medicalized circumcision of girls; prioritizing the privacy of circumcised women over the needs of medical students' training; and ensuring that infibulated women and women with other types of $\mathrm{FGM} / \mathrm{C}$ receive the medical care they need or could benefit from. Discrimination and ignorance within health services often results in women's reluctance to present for antenatal and gynecological care or for urinary and reproductive tract infections. ${ }^{31}$

All professionals have roles in identifying and reporting concerns about girls at risk of or affected by $\mathrm{FGM} / \mathrm{C}$ to authorities. Whilst not bound by a duty to report FGM/C, professional responsibility for action lies with the individual practitioner, with professional confidentiality generally covered by Child Protection laws. ${ }^{32}$

While the health risks of women affected by FGM/C have clear implications for medical professionals, the risks of professional racism, fear, and ignorance can isolate FGM/C practicing communities leaving women without appropriate medical care and children at risk of being cut. Bansal et $\mathrm{al}^{29}$ recommend that medical staff respond sensitively to women's specific medical needs, counsel couples about the risks and illegality of re-infibulation, and refer them to support and counseling from social workers, especially if their child is a girl.

\section{Roles and responsibilities of social and welfare workers}

From a framework of social justice and human rights, social and welfare workers have roles in advocating the need for cultural awareness and respect for migrants and refugees, particularly women affected by FGM/C, whilst addressing 
the rights of girls not to be cut. Other roles include mediating intergenerational cultural conflicts and child safety within families and facilitating education, engagement, and empowerment amongst practicing communities.

Social and welfare workers should first inform themselves about the contexts of FGM/C practicing communities in order to respond and inform others of the structural, emotional, and practical problems facing refugees and migrants as they settle. Challenges include economic hardship, unemployment, finding secure housing, and dealing with racism, discrimination, and personal and emotional issues, including trauma. ${ }^{33}$ Facilitating cross-cultural conversations requires empathy and critical self-reflection. "Western women need to ... be compassionate .... Ask questions. Listen, don't judge [....]". ${ }^{34}$ All professionals, including interpreters, ideally female, nonfamily members, need to manage their responses to minimize the discomfort for women and girls to discuss personal issues confidentially. ${ }^{28,30}$

Second, social workers have a responsibility to advocate the rights of girls not to be cut. This can be done through representatives from schools, local authorities, health professionals, and the police. Welfare professionals can overlook risks for children from refugee and migrant communities out of culturally relativist fears of being seen as racist, which can impair their judgment about appropriate interventions. ${ }^{33,35}$

In situations where a girl is considered at risk of FGM/C, the first priority is for her protection. The least intrusive legal action should be taken to ensure her safety and well-being, ${ }^{30}$ including engaging community organizations to facilitate work with parents and other family members. It is important to provide clear information about laws prohibiting FGM/C and the consequences of cutting, which may be difficult conversations because of peoples' past experiences of authority in oppressive regimes.

The way in which "social workers, doctors and police approach parents in situations of suspected abuse has a significant bearing on their subsequent reactions and the actions they take in response to the allegations". ${ }^{36}$ Conversations should be conducted with sensitivity rather than focusing on their suspected intention to harm their child. Accusing parents of trying to harm their child and breaking the law are likely to evoke denial and defensiveness. Forcing a family to break with a cultural practice can cause grief, anger, humiliation, and resistance and can send that practice underground. Acknowledging that parents have their daughters cut out of love can be harnessed as the point to leverage change. "The same factors that motivate a parent's decision to have their child cut may also spur a decision to stop the practice". ${ }^{11}$
Turnell and Essex ${ }^{36}$ advocate focusing on establishing future safety rather than forcing admissions of guilt.

Al-Krenawi and Graham ${ }^{37}$ suggest recruiting cultural mediators, community leaders who are respected and known in their community, for their opposition to FGM/C. Using traditional stories and proverbs, a cultural mediator can interpret cross-cultural norms about expressing emotions and acknowledging pain. They can educate professionals who may focus on this aspect of traditional practice from a mainstream dominant, wealthier, and more educated cultural perspective. As consultants, cultural mediators can enlighten professionals about FGM/C laws and be ambassadors of new ways. ${ }^{37}$

In a Canadian project, mediators raise important questions to be discussed between cultural insiders and outsiders: What are your thoughts about circumcising your daughter when the laws here forbid it? How have others in your community dealt with this? What hopes and fears do you have for your daughters growing up here where there's a liberal approach to women's sexuality? ${ }^{38}$

Further research is needed to establish how migrant communities navigate these complex cultural, moral and legal dilemmas.

Good management of the risks associated with FGM/C requires coordination between child protection workers, law enforcement officials, other practitioners and services, and representatives of affected communities. In the UK, section 47 of the Children Act 1989 requires a strategy meeting with local authorities, children's social care, health professionals (school nurse, health visitor, or community/hospital pediatrician), police, and the referrer (often a school) as soon as practicable (within 2 working days at most). Minutes of the meeting and the decisions taken must be recorded. ${ }^{30}$

Third, social workers can mediate intergenerational cultural conflicts within families and communities. For example, social workers should be ready to respond to young migrant and refugee women who want to try to make sense of what was done to them, without blaming and judging them or their families. A 24-year-old Australian woman Khadija Gbla who came as a refugee from Sierra Leone aged 13 highlighted this need at an Australian national forum on FGM/C. ${ }^{39}$ She spoke of her grief and horror when a doctor declared her "mutilated", through which she discovered that her clitoris had been cut off when she was a girl. She asked professionals at the forum for help for young women like her to deal with the confusion and loss. Whilst she understood that her mother had arranged her circumcision thinking it was in her best interests, she was angry with her for having taken from her the essence of womanhood as portrayed by women's magazines. Khadija suggested that 
a telephone help line of well-informed counselors should be established to respond to the growing number of young women becoming aware of their loss. How, she asked, do we ask our mothers about what was done to us? How do we talk with boyfriends about what's not there? ${ }^{6}$

With knowledge of the cultural contexts of FGM/C practices, social workers can advocate for culturally-sensitive medical and legal assessment, provide or refer young women to counseling and support to deal with grief and trauma they may have experienced, and promote family counseling to ensure the family understands the reasons for the legislative response and support each other through the transition.

Fourth, social workers can facilitate education, engagement, and empowerment amongst practicing communities. Migrant parents who observe the sexual liberation of young people in Western society do not know how to protect their daughters from promiscuity without the "security" of FGM/C. ${ }^{38}$ New cultural values and practices, including gender relationships and child rearing and discipline, can be confusing and potentially frightening. It can be helpful for host and migrant community parents to share their dilemmas. Some studies have found that in certain migrant communities, parents' intentions to have FGM/C performed on their daughters fade quickly when there are opportunities for discussion and debates. ${ }^{4}$ Factors supporting abandonment of the practice include:

education about the physical and mental health consequences of $\mathrm{FGM} / \mathrm{C}$, increased awareness in communities that there is no religious obligation for FGC, awareness that FGC is illegal in [the new country], and changing gender relations within communities. ${ }^{40}$

Working toward abandonment of FGM/C must use a "bottom-up" community-led approach to address the deeply held embedded traditional values and beliefs. In working individually with women and children affected by the practice, professionals should find ways to include family, male partners, and community leaders. All community members should be encouraged to report any suspected cases of FGM/C, and be informed that they can report anonymously if they fear community consequences. Cross-cultural educational exchanges should be part of the day-to-day work with practicing communities, to support their discovery of their own initiatives. ${ }^{30}$

\section{Conclusion and recommendations: challenges and opportunities}

FGM/C is a complex, emotionally charged and contested issue that persists because of its deep, culturally embedded meanings. It causes irreparable harm to girls and women and violates their fundamental human rights. Despite global prevention programs and laws operating for several decades, and some hopeful signs of abandonment, one in eight or nine girls from practicing countries is currently at risk of being circumcised, whether in their country of origin or settlement. Health and welfare professionals should be informed about FGM/C practices and develop ways to talk sensitively with women and children about the practice of FGM/C to prevent further harms and reduce the risks of racism, exclusion, and fear. This article has identified areas in which health and welfare practitioners in front line services can strengthen their knowledge and skills for practice in this sensitive context.

\section{Disclosure}

The author reports no conflicts of interest in this work.

\section{References}

1. Costello S, Quinn M, Tatchell A, Jordan L, Neophytou, K. Female genital cutting, a tradition in transition: a literature review on prevention, and demographic data for Australia. Melbourne, Australia: Family Planning Victoria; 2014. Available from: http://www.fpv.org.au/fgc. Accessed February 8, 2014.

2. World Health Organization. Eliminating FGM: an interagency statement UNAIDS, UNDP, UNECA, UNESCO, UNFPA, UNHCHR, UNICEF. Geneva, Switzerland: World Health Organization; 2008. Available from: http:/www.who.int/reproductivehealth/publications/ fgm/9789241596442/en/. Accessed January 1, 2011.

3. World Health Organization. Female Genital Mutilation. Fact sheet $\mathrm{N}^{\circ} 241$. [Updated February 2014]. Available from: http://www.who. int/mediacentre/factsheets/fs241/en. Accessed December 3, 2014.

4. United Nations Children's Education Fund. Female Genital Mutilation/ Cutting: A Statistical Overview and Exploration of the Dynamics of Change. New York, NY: UNICEF; 2013.

5. Earp B. Female genital mutilation (FGM) and male circumcision: should there be a separate ethical discourse? Practical Ethics. 2014. Available from: https://www.academia.edu/8817976/Female genital_mutilation_FGM_and_male_circumcision:_Should_there_ be_a_separate_ethical_discourse? Accessed November 8, 2014.

6. Costello S, Quinn M, Tatchell A, Jordan L, Neophytou K. In the Best Interests of the Child: Preventing Female Genital Cutting (FGC). The British Journal of Social Work. 2013;43(8):1463-1684.

7. United Nations Children's Education Fund. Changing a Harmful Social Convention: Female Genital Mutilation/Cutting. United Nations Children's Fund. 2005. Available from: http://www.unicef-irc.org/ publications/pdf/fgm_eng.pdf. Accessed July 24, 2013.

8. Costello S. (Executive Director) Tradition in transition: African women discuss why they have abandoned female genital cutting [Video]. RMIT University, Melbourne, Australia. 2014.

9. FGM Day. Personal communication. Meeting of Australian African workers to discuss the work in family and reproductive rights education Melbourne Australia. February 6, 2011.

10. Caldwell J, Orubuloye I, Caldwell P. Female genital mutilation: conditions of decline. Population Res Policy Rev. 2000;19(3):233-254.

11. Innocenti. The Dynamics of Social Change: Towards the Abandonment of Female Genital Mutilation/Cutting in Five African Countries. Florence, Italy: The UNICEF Innocenti research Centre; 2010.

12. Leye E, Mergaert L, Arnaut C. Female genital mutilation in the European Union and Croatia. 2013. Available from: http://eige.europa.eu/sites/ default/files/EIGE-Report-FGM-in-the-EU-and-Croatia.pdf. Accessed December 29, 2014 
13. International Organization for Migration. Supporting the Abandonment of Female Genital Mutilation in the Context of Migration. 2009. Available from: http:/www.iom.int/jahia/webdav/shared/shared/mainsite/projects/ documents/fgm_infosheet.pdf. Accessed July 20, 2013.

14. Merli C. Male and female genital cutting among Southern Thailand's Muslims: rituals, biomedical practice and local discourses. Culture Health Sexuality. 2010;12(7):725-738.

15. Macfarlane AJ, Dorkenoo E [webpage on the Internet]. Prevalence of Female Genital Mutilation in England and Wales: National and local estimates. Tables. London: City University London in association with Equality Now; 2015. Available from: http://openaccess.city.ac.uk/12382/ Accessed October 8, 2015.

16. ABC. UK holds first trial over female genital mutilation for doctor who performed procedure on woman who had just given birth. Available from: http://mobile.abc.net.au/news/2015-01-20/uk-holds-first-trialover-female-genital-mutilation/6026808. Accessed January 30, 2015.

17. Banks E. Female genital mutilation and obstetric outcomes: WHO collaborative prospective study in six African countries. Lancet. 2006; 367(9525):1835-1841.

18. Knight R, Hotchin A, Bayly C, Grover S. Female genital mutilation experience of the Royal Women's Hospital Melbourne in Australian. J Obstet Gynaecol. 1999;39(1):50-54.

19. Brusa M, Barilan M. Cultural circumcision in EU public hospitals - an ethical discussion. Bioethics. 2009;23(8):470-482.

20. United Nations (UN), Report of the International Conference on Population and Development, Cairo 5-13 September 1994. [webpage on the Internet] UNITED NATIONS POPULATION INFORMATION NETWORK (POPIN). Available from: http://www.un.org/popin/icpd/ conference/offeng/poa.html. Accessed June 29, 2015.

21. Barber R. Shifting the cultural norms: working to eradicate female genital mutilation in Somalia. 2009. Available from: http://www. worldvision.com.au/Libraries/AnnualProgramReview09_CaseStudies/ Shifting_the_Cultural_Norms.sflb.ashx. Accessed January 25, 2011.

22. Poldermans S. Combating female genital mutilation in Europe: comparative analysis of legislative and preventative tools in the Netherlands, France, the United Kingdom, and Austria [PhD thesis] Austria, Vienna: European University of Vienna; 2006.

23. Guiné A, Fuentes F. Engendering redistribution, recognition, and representation: the case of female genital mutilation (FGM) in the United Kingdom and France. Politics Soc. 2007;35(3):477-519.

24. Johnsdotter S. FGM in Sweden: Swedish legislation regarding "female genital mutilation" and implementation of the law. Research Report in Sociology 1. Department of Sociology, Lund University, Sweden. 2004.

25. Johnsdotter S, Moussa K, Carlbom A, Aregai R, Essen B. Never my daughters: a qualitative study regarding attitude change toward female genital cutting among Ethiopian and Eritrean families in Sweden. Health Care Women Int. 2009;30(1-2):114-133.
26. Mathews B. Female genital mutilation: Australian law, policy and practical challenges for doctors. Med J Aust. 2011;194(3):139-141.

27. Ierodiaconou M. Listen to us! Female genital mutilation, feminism and the law in Australia. Melbourne Univ Law Rev. 1996;20:562-587.

28. Jordan L, Neophytou K. A service coordination guide: improving the health care of women and girls affected by female genital mutilation/ cutting. Melbourne, Australia: Family Planning Victoria; 2012.

29. Bansal S, Breckwoldt M, O’Brien, Green S, Mbugua S. Female Genital Mutilation: Information for Health-Care Professionals Working in Ireland. 2nd ed. Dublin, Ireland: AkiDwA; 2013.

30. Foreign and Commonwealth Office, Great Britain. Multi-agency practice guidelines: female genital mutilation. 2014. London, England: HM Government. Available from: http://www.gov.uk/fgm. Accessed December 18, 2014.

31. Allotey P, Manderson L, Grover S. The politics of female genital surgery in displaced communities. Crit Publ Health. 2001;11(3):189-201.

32. Williams M. Confidentiality of the medical records of HIV-positive patients in the United Kingdom - a medicolegal and ethical perspective. Risk Manage Healthcare Policy. 2011;4:15-26.

33. Patrick I, Markiewicz A. Female genital mutilation: challenges for child welfare in an Australian context. Child Aust. 2000;25(1):13-20.

34. Khaja K, Lay K, Boys S. Female circumcision: toward an inclusive practice of care. Health Care Women Int. 2010;31:686-699.

35. Kriz K, Skivenes M. 'Knowing our society' and 'fighting against prejudices': how child welfare workers in Norway and England perceive the challenges of minority parents. Br J Social Work. 2010;40: 2634-2651.

36. Turnell A, Essex S. Working with Denied Child Abuse: The Resolutions Approach. Maidenhead, UK: Open University Press; 2006.

37. Al-Krenawi A, Graham J. The Cultural mediator: bridging the gap between a non-Western community and professional social work practice. Br J Social Work. 2001;(31):665-685.

38. Daniel S, Denetto S, Migliardi P, Plenert L. Our Selves Our Daughters: Community Engagement and Consultations Report. Winnipeg, Manitoba: Sexuality Education Resource Centre (SERC); 2009. Available from: http://www.serc.mb.ca/sites/default/files/resources/Our_Selves_Our_ Daughters_Engagement_Consultations_Report_2009.pdf. Accessed October 12, 2013

39. FGM Summit (2013) Personal Communication. Australian Government National Summit on Female Genital Mutilation. Parliament House. Canberra Australia. April 9, 2013. Available from: http://www.health. gov.au/internet/main/publishing.nsf/Content/report-fgms. Accessed October 12, 2014

40. Vaughan C, White N, Keogh L, Tobin J, Ha B, Ibrahim M, Bayly C. (2014). Listening to North Yarra Communities about female genital cutting. Melbourne, The University of Melbourne.
Risk Management and Healthcare Policy

\section{Publish your work in this journal}

Risk Management and Healthcare Policy is an international, peerreviewed, open access journal focusing on all aspects of public health, policy, and preventative measures to promote good health and improve morbidity and mortality in the population. The journal welcomes submitted papers covering original research, basic science, clinical \& epidemio-

\section{Dovepress}

logical studies, reviews and evaluations, guidelines, expert opinion and commentary, case reports and extended reports. The manuscript management system is completely online and includes a very quick and fair peerreview system, which is all easy to use. Visit http://www.dovepress.com/ testimonials.php to read real quotes from published authors. 